\title{
Ethnic Migration in North-West Inger- manland: The Influence of Economic Development on Local Differences in the Second Half of the 19th Century ${ }^{1}$
}

\author{
ANDREI KALINITCHEV, Ph.Lic., Ph.D. Candidate, Department of \\ General history in the University of Turku, Finland
}

\begin{abstract}
Ingermanland became a destination point for migrants of many nationalities and had an inner circulation of the domestic population in the 19th century. Migratory routes, as well as the outflow and inflow volumes in the region differed for each ethnic group. A micro-historical approach enables one to assess the various reasons for the mobility of the homogeneous domestic population. There was a specific migration of orphans to Lutheran Finnish communities. Indeed the main reason for this migration was due to economic factors. A structural change of employment in the case of the closure of factories resulted in the outward movement of the population, alongside the allure of higher wages in localities with an industrial and trade infrastructure. The expansion of St. Petersburg's city border led to complex migratory processes as a result of the rapid economic development of the capital region. Ingermanland became an important part of the international market exchange that created opportunities for migrants and businesses of residents affected by the changes, who increasingly gave up agricultural production and sought other ways of earning a livelihood.
\end{abstract}

Keywords: Ingermanland, migration, microhistory, ethnic group, orphan, social profile, income

\section{Introduction}

Geographical mobility of human resources was one of the major factors that influenced the economic development in the Karelian Isthmus. The Russian capital St. Petersburg became the destination point for population inflow for many inhabitants of the North-West region, for example for Finns (Engman 1983, 2004). Human resources tended to moved within the region due to uneven economic growth (Hämynen 1993). The new urban centres of growth which appeared on the Karelian isthmus needed a plentiful supply of manpower. Thus, the periphery began to lag behind and could not offer attractive reasons to stay (compare: Zarković 2002, 15-17). 
Opportunities for starting all manner of production units (Tjulpanov 1965) and different business activities were fostered by new technologies, the expansion of local and European markets and better logistics. This new economic scenario led to a situation that created new achievements in science and engineering, railway construction and the active exploitation of local natural resources. It also resulted in an increased demand for labour in the area and led to the redistribution of labour resources. In the course of this process industrial and trade zones appeared in the traditionally agricultural province (Orlova 1977; Birzhakov 2007).

There are some geographical terms and old Russian concepts used in the present article. Ingermanland was a historical region that comprised territories that bordered Old Finland and the Gulf of Finland to the north and north-west, the River Narva to the west, the southern border as it was settled according to the Treaty of Stolbovo (1617), as the River Lava and Lake Laatokka to the east. The total area of Ingermanland was 15,000 square kilometres (Nevalainen \& Sihvo 1991, 9). Old Finland is a name used to describe the area that Russia gained from Sweden during the period between 1721 and 1743, including Käkisalmi County, Viipuri County and the areas in southern Karelia that were east of the River Kymi and around Savonlinna. The other part of Finland was only later attached to the Russian empire and was subsequently known as New Finland. In 1812, Old Finland was joined to the autonomous Grand Duchy of Finland as Viipuri province.

The indigenous people of Ingermanland were Orthodox Ingrians and Votes. The territory was inhabited by Russians during the epoch of Novgorodian and Muscovite dominion ( $12^{\text {th }}$ century to the $15^{\text {th }}$ century). In the $16^{\text {th }}$ century the region bore the brunt of the increasing military conflict between Sweden and Russia. After the Swedish conquest of the region in the early seventeenth century, the area was settled by Lutheran Finns, who became the majority as many of the Orthodox population moved away.

The volost was a traditional administrative subdivision in Russia and consisted of several villages. Neighbouring volosts were grouped together into districts, which in turn formed part of larger governorates. Volosts were governed by an administrative system, which consisted of an elected chief, a representative of the villages, clerks and other officials elected by the Volost Assembly. In 1864 the Russian central authorities established the zemstvo system, which was a form of local government that functioned on the level of districts and governorates.

The aim of this article is to analyse migration among different ethnic groups that settled in the frontier region of the Grand Duchy of Finland. More specifically, the article will study North-West Ingermanland (excluding the urban population of St. Petersburg that did not form part of the administrative district of St. Petersburg) and will consider the influence of economic factors, such as the development of local industries, businesses and trade and employment, as well as the impact of the capital city and 
its markets on the north-western region during the second half of the $19^{\text {th }}$ century. A social profile of residents and immigrants will be provided alongside an examination of the income structure of the population that lived in different zones. The author uses a micro-historical approach to the subject in the present article, as Ingermanland was comprised of a complex a multiethnic population and its living environment was diverse and its determinants were also very numerous. Within Ingermanland economic factors were liable to vary every ten or twenty kilometres, which is why the influence of a phenomenon could have an impact on a relatively small part of the Ingrian population and could affect different ethnic groups in various ways. This is a contributory factor that determined the limitations on the scale of the subject to be researched and led to a focus on the rural north-western area of Ingermanland.

According to George G. Iggers, the use of a micro-historical approach is appropriate in cases in which the traditional methodology of social sciences is inapplicable or undesirable as a result of the impossibility of substantiating generalisations and conclusions stemming from everyday life. It seems that some research that was undertaken was based on large areas and quantitative sources that distorted reality at a grassroots level (Iggers 1997, 108, 232). Giovanni Levi supposed that a reduction in the scale of research in an experiment, which was founded on the assumption that the study of a living environment included relations and variables, can lead to mistakes and contradictions (Levi 1991, 95, 107).

\section{Ethnic groups registered in the $1882-85$ census}

Rural North-West Ingermanland had a common border with Old Finland and the Gulf of Finland on the west, the district of Pähkinälinna to the east, Lake Laatokka to the north and the district of Tsarskoye Selo to the south, which lay just outside the metropolis of St. Petersburg. Russians, Finns, Germans and Ingrians were the most numerous nationalities in Ingermandland, but the region also had Polish, Jewish, Latvian and Estonian ethnic minorities. These minority groups were relative newcomers to the northern rural areas of the region and only settled in the second half of the 19th century. One can divide the territory of North-West Ingermanland into three large zones: the northern agricultural zone was characterised by a dominant Finnish population (the volosts of Korkiomäki, Kylänjatko, Lempaala, Vartiamäki, Haapakangas and Valkeasaari), German colonies (Novosaratovskaya and Srednerogatinskaya), and also suburban and industrial areas (the volosts of Siestarjoki, Muurina, Parkala, Kivinenä, Polsteri, Moskovskaya, Aleksandrovskaya, Tuntia and Ust-Izhora) (see Map 1). 
Map 1. The localities of North-West Ingermanland (by A. Kalinitchev) (Keppen 1849, Köppen 1867, 50-52).

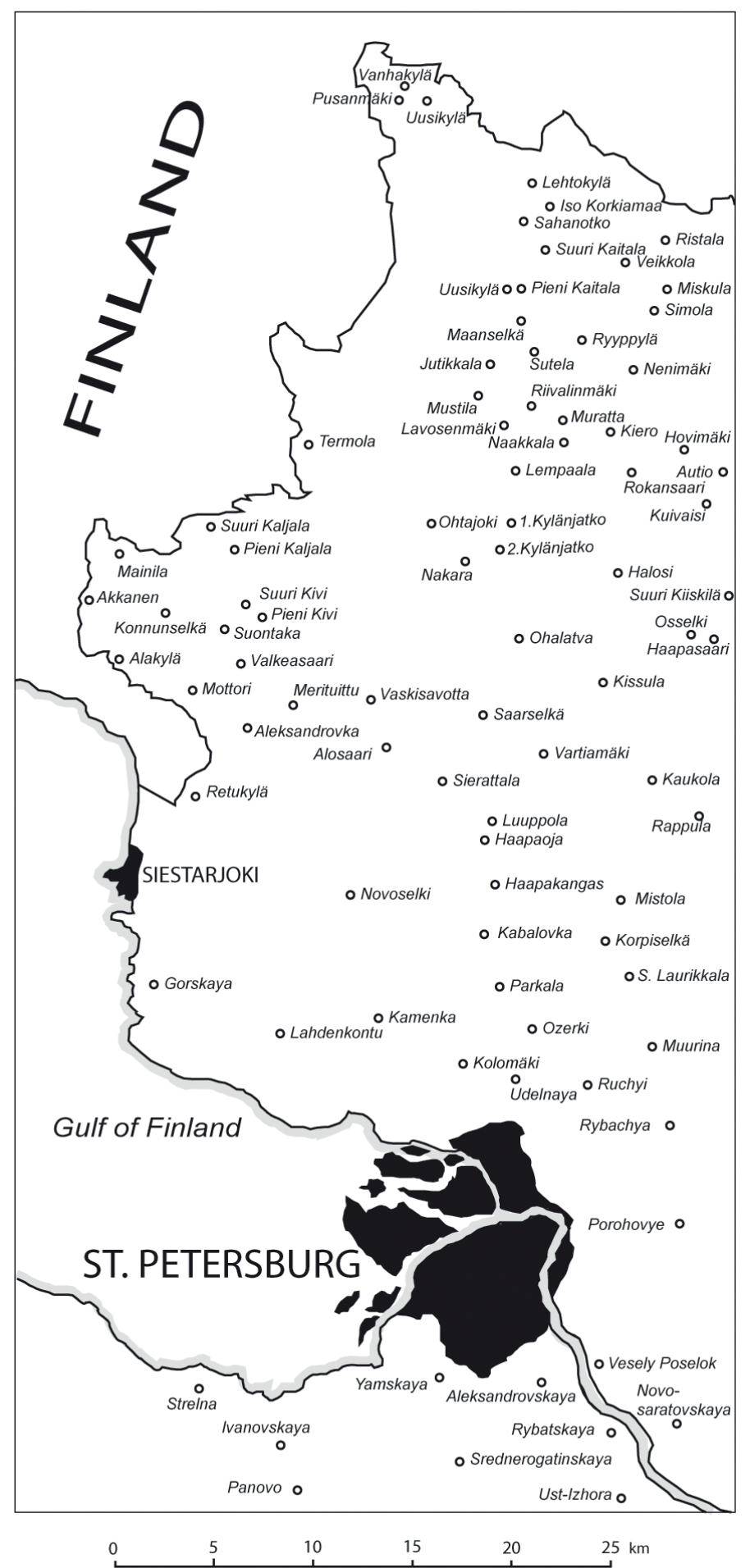


The 1882-83 census conducted in the district of St. Petersburg consisted of two parts: the first part recorded individuals and their households that belonged to the peasant communities, and whose land was less than 50 dessiatinas in size. This section included a respondent's personal data: nationality, age, occupation etc. (Materialy 1885; Materialy 1887). The second part only recorded information relating to landowners whose property exceeded 50 dessiatinas, but did not include information about nationality or age. Indeed the census only recorded the name of a landowner and his estate and whether he was local or a migrant (landowners who were born in Finland were grouped together with the representatives of the Baltic nations) (Materialy 1891). The second part of the census did not provide information about the other members of a landowner's family or about the servants who resided in his property. Hence, one cannot glean accurate data about the nationalities of the individuals mentioned in the second part of the census, and consequently it does not seem appropriate to add them to the ethnic data provided in the first part. The total amount of landowners who owned middling or large estates in the district of St. Petersburg (excluding the capital city) was 3,391 (419 individuals in 1865 and 1,385 individuals in 1877). These individuals can be added to the overall number of residents in the area and consequently they account for $6 \%$ of the local population (bearing in mind the fact that the census did not record members of a landowner's family or his servants). Thus, sections of the population were absent from the area's census records. Furthermore, the nationality of those who were recorded in the second part of the census is unclear. In addition, it should be noted that the census did not record clergymen and soldiers. Instead, the 1882-83 zemstvo census provides a researcher with unique information about people who lived in the peasant communities.

According to the data gathered by the census carried out by the zemstvo in the St.Petersburg governorate in 1882-85, the total population influx to North-West Ingermanland, or the district of St. Petersburg, was more than 55,000 individuals and thus exceeded the number of the permanent inhabitants $(36,040)$ (see Table 1, 2 and 3$)$. The migrants did not settle down uniformly and proportionally in the district, preferring to lodge near factories, trading areas and on the outskirts of the city. The measured inflow volumes between areas differed by up to 50 times and even up to 150 times between inhabited localities (Materialy 1887, 232).

The newcomers, who settled in such large industrial and trading volosts as Moskovskaya and Aleksandrovskaya, exceeded the numbers of the local population by a ratio of almost 7.5 to 1 . The local population was dispersed among the migrants in the communities. The census counted 23,533 immigrants in Moskovskaya and 6,663 in Aleksandrovskaya. In comparison with these figures the migration to the northern parts of the district of St. Petersburg was very small. Nevertheless, the northern agricultural zone and the entire northern quarter of Ingermanland had a positive migratory balance. 
The volosts of Kylänjatko and Valkeasaari, for example, which according to our classification belonged to the northern agricultural zone, had a population inflow that consisted of representatives from different ethic groups. There were 247 immigrants in the former, with 120 Russians (70 men and 50 women), 113 Finns (56 men and 57 women) and 15 persons from other nationalities. In the latter there were $273 \mathrm{im}$ migrants: 96 Russians (38 men and 58 women), 170 Finns ( 86 men and 84 women) and 7 persons from other nationalities.

Table 1. The ethnic groups of the local population in the district of St. Petersburg in the 1880s (Materialy 1887, 34).

\begin{tabular}{lr}
\hline Russians & 21718 \\
Finns & 10967 \\
Germans & 2197 \\
Ingrians & 1027 \\
Jews & 89 \\
Poles & 37 \\
Estonians & 11 \\
\hline
\end{tabular}

The local labour market and free available accommodation for the newcomers were important circumstances that defined the volume of the population influx. As a result, the volume of new migrants to the Moskovskaya and Aleksandrovskaya volosts was the highest.

It is necessary to notice that along with the migratory routes, which started in the north and brought a population from Old and New Finland, Karelia, Northern Russia and Northern Europe, the main migratory streams came to the St. Petersburg district from the south and from other Russian governorates. The migrants headed to the imperial capital and its adjacent communities. Only a relatively small percentage of migrants moved to locations north of the capital, in comparison to the number who settled in industrial and suburban areas. The majority of migrants that arrived in the St. Petersburg district were ethnic Russians $(49,386)$, followed by Finns $(3,126)$ and Germans $(1,329)$. Only sixty-five Ingrians from the Karelian isthmus migrated to the greater St. Petersburg behind, which ranks this ethnic group behind Jews (309), Poles (341), Latvians and Estonians (413) and representatives of other nationalities (296) (Materialy 1887, 35). The ethnic diversity of Ingermanland in the second half of the 19 th century was also bolstered by the influx of Poles, Jews, Estonians and Latvians, who previously comprised a relatively small percentage of the area's population (see Table 1). It can also be noted that the Russian population increased considerably during the period under consideration, whilst only a moderate number of Germans moved into the area. What is more, only a small number of Finns moved into Ingermanland, whilst the indigenous Ingrian population only increased very slightly. 
Table 2. The ethnic migrant groups in the district of St. Petersburg in the 1880s (Materialy 1887, 35).

\begin{tabular}{lr}
\hline Russians & 49386 \\
Finns & 3126 \\
Germans & 1329 \\
Estonians \& Latvians & 413 \\
Poles & 341 \\
Jews & 309 \\
Others & 296 \\
\hline
\end{tabular}

Table 3. The growth of the ethnic groups in the district of St. Petersburg in the 1880s (Materialy 1887, 35).

\begin{tabular}{lccrc}
\hline & Residents & Migrants & Total & Growth, \% \\
\hline Russians & 21718 & 49386 & 71104 & 227 \\
Finns & 10967 & 3126 & 14093 & 29 \\
Germans & 2197 & 1329 & 3526 & 60 \\
Ingrians & 1027 & 65 & 1092 & 6 \\
Jews & 89 & 309 & 398 & 347 \\
Estonians \& Latvians & 11 & 413 & 424 & 3755 \\
\hline
\end{tabular}

Migratory routes and destinations varied according to each ethnic group. The data from the 1882-85 Zemstvo census specifies that the number of newcomers of Russian origin was the least in the volosts of Vartiamäki and Haapakangas, which had a Finnish majority. In contrast, the most ethnic Russians were found in the volosts of Moskovskaya (more than 23,500), Aleksandrovskaya (more than 6,000) and Polsteri (more than 5,000), with the German-dominated Novosaratovsaya volost also being home to almost 5,000 Russians. The number of Finnish migrants was the biggest in the industrial town of Siestarjoki (370), which was situated next to the Finnish-dominated northern agricultural zone. Finnish migrants also had a strong presence in the multicultural volosts of Moskovskaya (386) and Polsteri (325) (Materialy 1887, 35).

\section{Polyethnic migration in the northern agricultural zone}

Russian ethnic migration in the northern agricultural zone centred on children and was organised by the Russian authorities. Orphaned children of all ages were delivered from across the governorate to the St. Petersburg foundling hospital and were recorded in the institution's registry as being ethnic Russians. They were given to Finnish adoptive parents, who received payment from the state (Ottshet 1866, 16). This explains why the growth of the Russian population in the northern zone did not equate to traditional forms of adult economic migration. 
In comparison with the 10th census that took place in 1858, the population of Kylänjatko in 1882 had grown by 24\%, whilst Korkiomäki had experienced growth of $21 \%$ and Lempaala's population had risen by $15 \%$ (Materialy 1887, 49). Such a significant resident population increase can be explained by the movement of Russian orphans, who had grown up in Finnish adoptive families and had secured membership status among the local rural communities (Svod 1872, 19). In the neighbouring volost of Valkeasaari, which also had a Finnish majority, the number of permanently living inhabitants only grew by $2 \%$. The reason for such a moderate increase can be attributed to the fact that the Finns in Valkeasaari did not adopt Russian orphans.

Bringing up foundlings had been a commercial activity for Finns for many decades. A Finnish family received an average payment of 33 roubles a year for an orphan. The populations of Korkiomäki, Lempaala and Kylänjatko increased by 1,439 in the 24 years prior to 1882 , as the increased number of orphans were recorded as being members of the local Finnish communities (Materialy 1887, 27). In addition to this figure, the total number of orphans in Finnish adoptive families in 1882 was 1,351 (Materialy 1887, 261).

Other kinds of migrants who came to the northern zone was invalids, elderly people, children wandering on their own and beggars without families which could take care of them (Ottshet 1866, 8-9). These people were supported and fed by local communities, Lutheran and Orthodox parishes, although there were few beggars among residents (Materialy 1885, 94, 124). Migrants of these types found shelter in the countryside escaping the capital police who detained beggars, tramps, infringers and Finns born in Finland but were living without a valid passport (Ottshet o dejatelnosti 1885, 5).

In addition, there was also another type of incomers to the St. Petersburg region; namely farmers from Finland who moved into the district's wastelands in order to work off the land. The local authorities saw a lot of potential in Finns, and consequently new Finnish households were established in Haapakangas, Vartiamäki and other volosts (Ottset 1866, 44-45). In the 1860s there were only 2 farms that belonged to peasants who were originally from Finland and were not members of peasant rural communities, whilst in 1888 their number had reached 63. In the great bulk of cases, they owned small households, from which 46 had less than 0.5 dessiatinas of land (approximately 0.55 hectares). Thus, they can be defined as having been land tenants (Materialy 1891, $14,38,88,100,101)$. Agricultural immigration from Finland was also recorded in the neighbouring district of Pähkinälinna, which was situated in the north-eastern part of Ingermanland (Materialy 1889, 39).

The new settlers from Finland faced practical problems, including bad infrastructure in the countryside (Ottshet 1866, 44-45). Nevertheless, there were several positive factors that helped in the running of the farms, such as the short distance to the consumer market and the low costs of local labour. 
The ethnically diverse migrants gave the region the benefit of their culture, education and experience and affected the social structure and the demographics of their local communities. When city dwellers (landowners, summer residents, professional workers) and Finnish farmers settled in the countryside, it raised the common level of local culture and the professional qualifications of people involved in the agricultural sector. What is more, their arrival acted as a stimulus for the development of local craft production and industries.

\section{Population migration}

The resident migration away from North-West Ingermanland was low, with a net figure of only 984 out of a total of 37,024 regional inhabitants. This figure corresponds to $2.7 \%$ of the local population. Economic factors had a considerable impact on this process. The principal causes behind the residents' migration were due to a shortage of agricultural land and the closure of factories, which were both brought structural changes to the regional employment situation. The case of the volost of Valkeasaari provides a good example of the difficulties faced by residents when a structural changes in employment affected a local labour market. The census recorded that 31 Finnish men and 14 women had left Valkeasaari before the 1882 census and that 27 Finnish men and 16 women had left Kylänjatko for the term exceeding seasonal work. Sixtytwo Russian men and 35 women from Valkeasaari and 15 Russian men and 16 women from Kylänjatko had also abandoned their native villages (Materialy 1887, 29).

In relative terms, the migration of Russians from Valkeasaari amounted to $37 \%$ of local men and $17 \%$ of women. This considerable migration of the Russian population was due to employment factors, since these Russians had had a history of working in factories, and thus it was easier for them to once again work in an industrial setting than for peasants (Kalinitchev 1998, 204-227). Due to the changes in the employment situation, Russians and Finns were compelled to search for new jobs elsewhere. If there were no jobs for sons at the factories where their fathers worked, they had to leave their homes for new working opportunities in the greater St. Petersburg region (Kalinitchev 1998, 121). Female family members usually stayed at home (Materialy 1887,31 ).

Other sources indicate that the incomes of these families were reduced because the communities of Aleksandrovka, Nakara and Vaskisavotta in the volost of Valkeasaari faced difficulties trying to implement farming initiatives after the local factories had closed (Ottshet o dejatelnosti 1885, 461-478). The structural change to the local economy led to migration among the local Russian and Finnish population, whose small plots were not able to provide a sufficient income for their families (Materialy 1887, 152-153).

In the neighbouring volost of Kylänjatko the migration of Russians was 7\% among both sexes. This figure corresponds to the fact that not all former Russian orphans who had been brought up in Finnish families stayed with their adoptive parents. The 
average migration of Russians in the district as a whole was much less and amounted to 3\% (Materialy 1887,29 ). This figure indicates that the local Russian population seldom migrated, whilst in the northern volosts, dominated by Finns, the migration of Russians exceeded the average rate.

The migration of local Finns from Valkeasaari and Kylänjatko was 3\% among men and nearly $1 \%$ among women. The local Finnish population almost never moved away from Haapakangas $(0.1 \%)$ and Vartiamäki $(0.5 \%)$ and the largely mono-ethnic volosts of the northern agricultural zone. However, the migration rate of those Finns who lived in Parkala, Kivinenä and Siestarjoki was high. In comparative terms, on average $6 \%$ of men and $4 \%$ of women moved away from the German communities (Materialy 1887, 29).

Research of ethnic migration in this region in the period in question indicates that Finns were more devoted to their place of birth. The population of agrarian communities appears to have been less mobile. Although some members of the $12 \%$ of Finnish families in Kylänjatko moved away, only 1.3\% of Finnish families (amounting to 5 families) moved away permanently. In the volost of Valkeasaari which was partly situated in an industrial zone, around 14\% of individuals from local families of both Finnish and Russian nationality left their homes, whilst only $4.8 \%$ of families permanently migrated.

There was an obvious reduction of plot areas per capita that led to peasant poverty when locals began to lose their insufficient land plots and move from their native villages in order to find comfortable incomes to support their families. Indeed, some family members did stay at home, but they did this because of the unfinished redemption operation that was launched in 1861. According to this redemption operation, plots were bought on communal property, but not on family or personal property. Once a family had left its community, it also lost its share in communal land ownership and all previous payments.

The 1882-85 census registered a migration of some Russians from Valkeasaari, but a majority of Finns - even landless families - preferred not to migrate. This can largley be seen as determined by the fact that they enjoyed solid ethnic relationships inside the Finnish communities.

In comparison with the Finns and Russians, the Germans who lived in the colonies of Srednerogatinskaya and Novosaratovskaya, migrated to new colonies established in territories that they had purchased in the governorate of St. Petersburg (Materialy 1887, 32). The German communities had a cultural tradition which involved the eldest son in a family inheriting all the family's landed property, whilst any other sons had to purchase landed property elsewhere for themselves (Bahmutskaja 1999; Shrader 1989, 1998). 


\section{Social profile of the residents and the migrants}

The analysis of the 1882-85 census data shows a close connection between the size and economic condition of a family. A traditional agrarian family, which either owned or rented plots, tended to be larger than the family of an industrial worker or a handicraftsman. An agrarian family from the northern zone usually consisted of six persons, while a family that only had an allotment with a house usually consisted of only three individuals. On average, a houseless or landless family only included two people (Materialy 1887, 51-52).

Migrants had fewer children living with them. The children of a newcomer often lived with the rest of a family in their native village. Hence, a migrant family normally had one less offspring with them than a resident family (Materialy 1887, 50). Migrant families also had less working-aged members. It was typical for a migrant family to have one working-aged member and sometimes to have no such member (Materialy $1887,50)$. Indeed, such a family was usually a single-parent family with one or two children. This means that an average migrant family was very vulnerable to economic misfortune in the social circumstances in which they lived in the 19th century, when financial support only came from family members. In the event of illness or accident a migrant could not receive any community support, so in the best case scenario he was forced to go and live with relatives.

The population of North-West Ingermanland was young. Children (boys aged 1-13 and girls aged 1-11) made up one-third of the population of Valkeasaari and Kylänjatko (Materialy 1887, 44). Together with the population of juvenile age (boys aged 14-17 years and girls aged 12-15) they made up almost a half of the inhabitants of Kylänjatko and more than one-third of the inhabitants of Valkeasaari. In general children and juveniles comprised on average only one-fifth of the population in the St. Petersburg district. Analysing the demographic situation in Valkeasaari, one should take into account that the population of the industrial area reduced the share of the youngsters in the general statistics.

It can be stated that the demographic situation in Ingermanland in the 1880 s attests that there were more children in the rural communities, where people made their living from agriculture. The statistics demonstrate that the closer to St. Petersburg and other industrial areas people lived, the fewer children they had. In several volosts that bordered the capital, such as Tuntia, Kivinenä and Moskovskaya, the share of the children and youngsters was only $11-19 \%$ and mortality exceeded fertility, which was indicative of negative population growth (Materialy 1887, 45). The influence of urban culture led to marriage at a young age becoming less popular, in combination with people not being able to afford to start a family.

The census registered 19 elderly people - men over 60 and women over 55 years old, or $2 \%$ of the population - in Kylänjatko and 8 elderly people, or $3 \%$ of the population 
in Valkeasaari. At the same time, there were $2 \%$ of the population classed as elderly in the district of St. Petersburg. The smallest percentage of elderly inhabitants occurred in the German colonies and in the industrial volosts (only one or two persons per $100 \mathrm{mi}-$ grant families), with the highest ratio being in the northern Finnish communities (10-30 seniors to 100 migrant families, at an average of four seniors to 100 migrant families in the St. Petersburg district) (Materialy 1887, 50). This fact demonstrates that the northern agricultural zone was a deemed to be suitable for elderly members of the population for non-residents as well as for residents. In regard to the German and factory communities, one can state that only working migrants tended to settle in these areas.

The statistics describes convey the hard conditions encountered by hired industrial or agricultural labourers in the 1880s. Migrants could not have afford to accommodate parents or to start their own families due to the high cost of living in the capital and the suburban areas. If a migrant had a child or parents, they usually stayed outside the St. Petersburg governorate, which in all likelihood was their home village. The traditional family, which consisted of three generations with two or three children, was maintained in the Finnish-dominated communities of the northern agrarian region. A local family in this area typically consisted of five or six members, while a migrant family only consisted of three or four persons. A family that lived in the industrial areas of Ingermanland typically comprised approximately three to five members, while a migrant family included one or two members (Materialy 1887, 48).

The census recorded that the largest families emanated from the German community, which on average included nearly seven persons, while a migrant household seldom had more than one person (Materialy 1887, 48). It means that the majority of migrants in this community were hired agricultural workers.

\section{Income structure}

During the 1880s the market behaviour of peasant households was focused on two or more types of business. The primary business of a family brought in to the household a major income, whilst other business activities amassed additional incomes. A household's income can be classified as being formed from agricultural and other activities. The income structure among the local population of Kylänjatko, for example, was comprised from a near equal split between agricultural enterprises and other activities. Among non-residents there was a ratio of $1 / 5$ and 4/5. Ingrian Finns traditionally worked in agriculture, but migrants did not have enough money to establish their own farms.

In the volost of Valkeasaari the local population obtained $38 \%$ of its income from agriculture and $62 \%$ from handicrafts or hired working, whilst for non-residents the equivalent statistics were $10 \%$ and $90 \%$ accordingly. Thus, it was a rare phenomenon for a migrant to earn a living from farming on rented plots, with the majority being hired workers or craftsmen. 
Indeed, the labour market functioned in such a scenario because 186 households - or $47 \%$ of the total amount in the volost of Kylänjatko and 152 households or $25 \%$ of all households in the volost of Valkeasaari - used hired worker labour (Materialy 1887, 157). This indicates that a property stratification process was taking place, whereby a section of the peasantry became rich farmers who needed to hire labour, whilst the other main section were compelled to become landless farm labourers. Workers were employed for both long and short terms: from several days to a whole season. An annual labourer was more cost-efficient for an employer on a daily basis, with the earnings of an annual worker averaging 30 roubles for women and between 43-52 roubles for men. The low level of profitability in the agricultural sector in the north ensured that salaries were kept at a low level.

Migrants constituted almost the entire hired workforce and craftsmen in the volosts of maximum population immigration. Agriculture formed the main source of income in the northern Finnish and German volosts. In terms of the Russian-dominated communities, agriculture was widespread in Muurina (Materialy 1887, 233).

The permanent sections of the population of these communities obtained extra income from a variety of sources: raising orphans, personal service, the renting of rooms for migrant workers and summer residences for vacationers, hired agricultural working, timber harvesting, horse-cab driving, horse-drawn transportation, factory labour, trading, the gathering of berries and mushrooms, milk production, craftwork, work as blacksmiths and coopers and sewing.

In the 1880s the average cumulative yearly income of a local inhabitant amounted to 37 roubles in Kylänjatko and 79 roubles in Valkeasaari, while a migrant's income was 35 roubles in the former and 37 roubles in the later. The cumulative income of a resident in the northern communities was considerably below the average income in the St. Petersburg district, or North-West Ingermanland, which at that time was 109 roubles, and the average income of a migrant was even higher, with an average sum of 159 roubles. The maximum income for a local person of working age is recorded as having been in Srednerogatinskaya (329 roubles) and Novosaratovskaya (292 roubles), with workers in Kivinenä receiving 194 roubles, 179 roubles in Moskovskaya and 168 roubles in Aleksandrovskaya.

It is necessary to note that earnings in the industrial and trade sectors were considerably higher than those in agriculture. Indeed, the difference was substantial among the newcomers (Materialy 1887, 233). Working in a small agricultural household entailed less profit than in other businesses. However, the large farms run by Germans and some nobles were an exception to this rule.

As a rule the closer an individual lived to St. Petersburg, the higher were their earnings. In northern communities in the greater St. Petersburg district, such as Kylänjatko and Valkeasaari, incomes were the lowest. Considerable differences were felt between average 
incomes in the northern communities and in the suburbs, such as in Aleksandrovskaya and Moskovskaya. The high incomes in the latter volosts can explain the high levels of immigration, as people preferred to move to communities with high levels of earning potential.

\section{The influence of economic migration}

The expansion of the borders of the capital area led to urbanisation in these zones, which, on the one hand, led to an economic boom and a population influx. However, on the other hand, it also led to population migration. The economic boom led to a rapid increase in land prices, which led to some peasant communities selling their lands and moving out to make available the space for more profitable businesses (Materialy 1887, 80-91). Thus, the arrival of some led to the departure of others. A change of employment structure accompanied the growth of industrial production and trade and the decline of farming. It can also be noted that the share of the population occupied in farming diminished as well, in regard to the change in the population structure during the course of migration.

In the second half of the 19th century the northern rural communities were incapable of receiving a significant number of migrants, because the level of production and the amount of natural resources was only sufficient for sustaining the local population. A lack of accessible land resources for the expansion of agricultural production became an obstacle for economic development in the northern rural communities. This was a result of the fact that the necessary agricultural lands were concentrated in the possession of landowners and the state. Active railway construction and the modernisation of water transportation improved regional logistical capacities, as well as stimulating local trade and became facilitated better links to international markets. All this led to a revival vis-à-vis cultural and economic exchange in the region. Indeed, the region became more attractive for businesses and for foreign and domestic financial capital.

The skills associated with factory working often reduced the barriers that prevented people from migrating. Consequently, the population of industrial areas became more mobile. An individual's willingness to migrate not only depended on his nationality, but also on the migration locality and a migrant's profession (compare: Trifonova 1999). A migrant's low estate was not only an obstacle for his or her social mobility, but also acted as a stimulus and channel for changing their place of living (Kalinitchev 2010a).

\section{Ethnic groups registered in the 1897 census}

The 1897 census that was conducted in the whole of the Russian Empire by the Central Statistic Committee (Pervaja 1903) was much more comprehensive than the 1882-83 zemstvo census. The census recorded the population of the district of St. Petersburg, although it did not provide any information about the settlement patterns of volosts situated in different parts of the district. Thus, it is impossible to define local differences when analysing the migration patterns of the district. 
According to the 1897 census there were a total of 53,273 rural residents in the district of St. Petersburg (excluding the city of St. Petersburg). Furthermore, of these residents 28,430 were men and 24,842 were women (Pervaja 1903, 5). Moreover, it is recorded that nearly 2,000 local residents were temporarily absent. In sum 19,359 newcomers were recorded in the census, with 5,954 having migrated from other places of the St. Petersburg governorate, 13,286 from other governorates and 119 from other states. The 1897 census used a different method to calculate the local population and the level of immigration than the 1882-83 census. If one analyses the dynamics of the resident population of the Ingrian countryside one can calculate that there were 36,046 residents in 1883 but only 33,913 in 1897 . Thus, if one compares the censuses one finds a population decrease of 2,133 , or $6 \%$, in fourteen years. However, the difference in the numbers of the immigrant population in the corresponding years is even more striking: 55,380 newcomers of all nationalities were recorded in the 1883 census, whilst only 19,359 are noted in the 1897 census. This amounts to a decrease of 36,021 individuals, which amounts to $65 \%$ less over fourteen years. Yet, it seems that the largest change was actually made in how newcomers were recorded, because such a massive change in migration patterns was not possible under normal circumstances in the 1880 s and 1890 s. Indeed, it is normally assumed that the region experienced growth in the volume of migration during this period. A logical explanation for this phenomenon could be that most of seasonal and temporary workers were recorded in the 1897 census in communities outside the district of St. Petersburg, where they had once lived and been registered previously. As will be demonstrated below, this tendency was particularly displayed by the sizeable Russian and German ethnic groups, whilst the Jewish, Estonian and Latvian groups remained approximately the same and the Finns and Poles became more numerous.

Instead of a category such as "nationality" the 1897 census used a term called "native language". At this time one's native language was deemed to indicate a person's nationality. Owing to the absence of records documenting divisions by nationality among locals and residents in the 1897 census, a dynamic ethnic analysis can only be made regarding the total population volumes recorded in both censuses.

According to the 1897 census, 31,484 individuals spoke Russian in the countryside in North-West Ingermanland, along with 17,760 Finnish speakers, 1,855 German speakers, 562 Polish speakers, 528 Estonian and Latvian speakers, 392 Jewish speakers and 384 individuals who spoke other languages (see Table 4) (Pervaja 1903, 90-95). This data concerned all the area's population, irrespective of divisions between residents and newcomers. One should note that not a single Ingrian speaker was documented as living in the countryside. It seems more than likely that the Ingrians were grouped with Finns in the category of "native language" on the grounds that both ethnic groups belonged to the Finno-Ugric language group (Pervaja 1903, 176). 
Table 4. The ethnic groups in the district of St. Petersburg in the 1897 census (Pervaja 1903, 90-95).

\begin{tabular}{lr}
\hline Russians & 31484 \\
Finns & 17760 \\
Germans & 1855 \\
Poles & 562 \\
Estonians \& Latvians & 528 \\
Jews & 392 \\
\hline Others & 384 \\
\hline
\end{tabular}

According to the 1897 census, Russians were the majority group in the St. Petersburg district, with Finns also constituting a 1/3 of the population. The 1897 census recorded that newcomers from Finland amounted to 2,277 individuals (25,844 newcomers from Finland were resident in the whole governorate), of whom $13 \%$ were Finnish speakers living in the rural part of north-west Ingermanland. The volume of recent migrants from Finland to the neighbouring region amounted to 18,240 and ranks as the second largest figure (after their migration to the city of St. Petersburg). This confirms the conclusions made by other researchers that migrants from Finland constituted a remarkable share of the Finnish population in north-west Russia (Engman 1983). In this sense the migration of Finns was most active in the border area because of communication and interaction in their ethnic group (Kalinitchev 2010b). The level of migration of minority ethnic groups, such as Poles, Jews, Estonians and Latvians, to rural areas in north-west Russia was low. This was partly because they could not forge sufficiently strong social networks. The population of Russians, Jews, Poles, Germans and other ethnic groups in the governorate of St. Petersburg and Ingermanland was mainly urban, whilst the Finnish and Ingrian population was predominantly rural (Pervaja 1903, 3).

\section{Conclusions}

The micro-historical analysis undertaken in the present study discovered that human resources moved from underdeveloped regions to those communities in which people obtained their living from working in factories and by trading. It can be noted that an inner circulation of manpower took place in the region. The influx of labour into the industrial sector, large farms and into the trade sector increased the common economic potential of the region.

The migration into Ingermanland had a substantial impact on the environment and the demographic situation of the area. While market economics was rapidly spreading after the abolishment of serfdom in 1861, population mobility also increased every year (compare: Malmberg 1997, 37). Rural communities became dependent on market forces - mainly the grain market - which led to a weakening of the communities' 
homogenous social structure, disruption of traditional peasant communities, social stratification and, finally, population migration.

A micro-historical analysis of the interrelationships within communities enables us to understand why one part of a population migrated, whilst another section remained in situ (Hägerstrand 1975, 3-14; Levinson and Christensen 2003, XXXIX; compare: Fischer, Reiner and Straubhaar 1997, 88). Local social and economic conditions were held in great stock in the process of forming these interrelationships. Emotional bonds and devotion to one's native land, as well as the idea of a national ethnic group were of great significance. Communication between communities of one ethnic group (for example Germans, Finns, Estonians etc.) made the mobility of its representatives much easier and softened cultural differences between communities and urban and rural population of the same nationality (Kalinitchev 2010b).

An analysis of the migratory processes in Ingermanland highlighted the importance of religious and ethnic aspects when studying population mobility. A person in the 19th century lived in both local - usually rural - and church communities. Having arrived in a new area newcomers joined the community of local residents. Religious feeling was high among rural inhabitants, and belonging to a particular denomination was a significant part of a person's national identity. Denominational unity helped the newcomers in terms of being accepted by the local population (compare: Park 1994, 155). Social connections that were based on national and religious unity created firm bonds within an ethic group. In sum, migration in Ingermanland was determined by the behaviour of different groups, which were formed on the basis of native language, denomination and ethnicity. There were subgroups within the main groups that were determined by migrational regions, sub-ethnic categories and occupation.

This state of affairs influenced the migration routes of different ethnic groups. Hence, Orthodox Russians preferred to move to communities in which their faith was practiced, whilst Lutheran Finns looked to settle in villages that reflected their religious outlook (Ottshet 1866, 8). As an ethnic minority Ingrians lived within communities with different cultural influences, which explains why they were members of both Lutheran and Orthodox communities (Istoriko-statistitsheskije 1884, 174-175; Hakamies 1991, 203; Sivonen 2007). Regarding the Finnish immigrants who moved from Finland, one should mention the sub-ethnic immigration of the Savakkos and Äyrämöinens (Saloheimo 1991, 1992, 1993; Sihvo 1991), who both preferred to settle in areas in which their own subgroup lived (Kalinitchev 2010b). Germans migrated across Ingermanland and founded new ethnic agricultural communities.

The Russian ethnic migration to the Finnish Lutheran communities occurred as terms of an influx of orphans into Finnish adoptive families. The majority of Russians stayed with their adoptive parents into adulthood and became members of Finnish rural communities (Ottshet o dejatelnosti 1885, 321-342). 
Ethnic identities and cultural features influenced the multicultural dynamic of the regional environment, included communities and social networks. Different local cultures from Finland (Ahlqvuist 1904, 207-219; Kuujo 1969, 63-70), Karelia, the north and governorates all over the Russian Empire took part in the migratory process. Their cultural traditions influenced their style of living and interrelations with other ethnic groups (compare: Tilly 1984, 83, 125).

\section{References}

Ahlqvist, A. 1904. Kertomus runonkeruumatkasta Viipurin läänissä v .1854 [Report on folklore expedition in the governorate of Vyborg in 1854]. In: Runonkerääjiemme matkakertomuksia 1830-luvulta 1880-luvulle [Reports of our folklorists 1830-1880], edited by A.R. Niemi, pp. 199-229. Helsinki: Suomalaisen kirjallisuuden seura.

Bahmutskaja, Elena. 1999. Obrazovanije nemetskih kolonij v Sankt-Peterburgskoj gubernii (vtoraja polovina 18 - natshalo 20 vv.) [Formation of German colonies in the governorate of St. Petersburg (from the second half of the 18th century to the beginning of the 20th century]. In: Nemtsy v Rossii, Peterburgskije nemtsy [Germans in Russia, Germans of St. Petersburg], edited by Galina Smagina, pp. 233-244. St. Petersburg.

Birzhakov, Mihail. 2007. Turistskij putevoditel po Leningradskoj oblasti [Tourist guide for Lenoblast]. St. Peterburg: Gerda.

Engman, Max. 1983. S:t Petersburg och Finland. Migration och influens 1703-1917. Helsingfors, pp. 1-453.

---. 2004. Suomalaiset Venäjällä. Lähdeopas. Helsinki, pp. 1-143.

Fischer, Peter A., Reiner Martin and Thomas Straubhaar. 1997. Should I stay or should I go? In: International migration, immobility and development: multidisciplinary perspectives, edited by Tomas Hammar, Grete Brochmann, Kristof Tamas and Thomas Faist, pp. 49-90. Oxford: Berg.

Hakamies, Pekka. 1991. Inkeri monietnisenä alueena [Ingermanland as a multiethnic region]. In: Inkeri: historia, kansa, kulttuuri [Ingermanland: history, people, culture], edited by Pekka Nevalainen and Hannes Sihvo, pp. 197-204. Helsinki: Suomalaisen kirjallisuuden seura.

Hägerstrand, Thomas. 1975. Space, time and human conditions. In: Dynamic allocation of urban space, edited by Anders Karlqvist, pp. 3-14. Farnborough, Saxon House.

Hämynen, Tapio. 1993. Liikkeellä leivän tähden: Raja-Karjalan väestö ja sen toimeentulo 1880-1940 [Moving for bread: Population of border-Karelia and its substinance in 1880-1940]. Helsinki: Suomen Historiallinen seura.

Iggers, Georg G. 1997. Historiography in the Twentieth Century: from Scientific Objectivity to the Postmodern Challenge. Wesley/University Press of New England, Hanover.

Istoriko-statistitsheskije svedenija o S-Peterburgskoj jeparhii. 1884. Volume 8. St. Petersburg.

Kalinitchev, Andrei. 1998. Ingermanlandskije finny $v$ imenii Kaidanovyh-Olhinyh 
Sankt-Peterburgskoj gubernii (1860-je gg.) [The Ingrian Finns in the manor of the Kaidanov-Olkhins in the governorate of St. Petersburg (the 1860s)]. The unpublished licentiate's thesis at the University of Turku, Department of General history.

---. 2010a. Aateliksi Venäjällä: Kaidanov-Olhinien suku 1700-luvulta 1900-luvulle [To become a noble in Russia: the Kaidanov-Olkhins family from the 18th to the 20th centuries]. Genos 4: 123-132.

---. 2010b. Etnisten ryhmien välinen vuorovaikutus Pohjois-Inkerissä 1800-luvun loppupuolella [The interaction among ethnic groups in North Ingermanland in the end of the 19th century]. Historiallinen Aikakauskirja 4: 451-464.

Keppen, Peter. 1849. Etnografitsheskaja karta Sankt-Peterburgskoj gubernii [Ethnographic map of the governorate of St. Petersburg]. St. Petersburg.

Kuujo, Erkki. 1969. Inkerin vaiheita keskiajalta 1700-luvun loppuun [The history of Ingermanland from the middle ages to the end of the 18th century]. In: Inkerin suomalaisten historia [The history of Ingrian Finns], edited by Sulo Haltsonen, pp. 45-96, Jyväskylä: Inkeriläisten sivistyssäätiö.

Köppen, Peter v. 1867. Erklärender Text zu der ethnographischen Karte des St. Petersburger Gouvernement [The explanations for the ethnographic map of the governerate of St. Petersburg]. St. Petersburg.

Levi, Giovanni. 1991. On microhistory. In: New Perspectives on Historical Writing, edited by Peter Burke, pp. 93-113. Cambridge.

Levinson, David and Karen Christensen. 2003. Encyclopedia of Community: From the Village to the Virtual World. Volume 1. Sage Publication (CA).

Malmberg, Gunnar. 1997. Time and space in international migration. In: International migration, immobility and development: multidisciplinary perspectives, edited by Tomas Hammar, Grete Brochmann, Kristof Tamas and Thomas Faist, pp. 21-48. Oxford: Berg.

Materialy po statistike narodnogo hozjajstva $v$ Sankt-Petergurgskoj gubernii. 1885. Volume 5. Part 1. St. Petersburg.

Materialy po statistike narodnogo hozjajstva v Sankt-Petergurgskoj gubernii. 1887. Volume 5. Part 2. St. Petersburg.

Materialy po statistike narodnogo hozjajstva v Sankt-Petergurgskoj gubernii. 1889. Volume 10. St. Petersburg.

Materialy po statistike narodnogo hozjajstva $v$ Sankt-Petergurgskoj gubernii. 1891. Volume 5. St. Petersburg.

Nevalainen, Pekka and Hannes Sihvo. 1991. Teoksen taustasta [About the book]. In: Inkeri: historia, kansa, kulttuuri [Ingermanland: history, people, culture], edited by Pekka Nevalainen and Hannes Sihvo, pp. 9-10. Helsinki: Suomalaisen kirjallisuuden seura.

Orlova, Irina. 1977. Dostoprimetshatelnosti Leningradskoj oblsti [Attractions in Lenoblast]. Leningrad.

Ottshet zemskoj upravy Sankt-Peterburgskogo ujezda. 1866. St. Petersburg.

Ottshet o dejatelnosti Sankt-Peterburgskogo ujezdnogo zemskogo sobranija i zemskoj upravy s 1 sentjabrja 1865 g. po 1 janvarja 1883 g. 1885. Sost. predsedatelem Sankt-Peterburgskoj zemskoj upravy I.I. Kusovym. St. Petersburg. 
Park, Chris C. 1994. Sacred World. An introduction to geography and religion. London.

Pervaja vseobshtshaja perepis naselenija Rossijskoj imperii 1897 g. 1903. Pod redaktsijej N.A. Trojnitskogo. T. 37, Ch. 1. SPb. 1-257.

Saloheimo, Veijo. 1991. Inkerikkoja, äyrämöisiä ja savakkoja. Inkerinmaan tulomuuttajat ja sisäiset liikkujat vuoden 1643 henkikirjan mukaan [Ingrians, Äyrämöinens and Savakkos. Immigrants and migrants in Ingermanland according to the 1643 church book]. Joensuun yliopisto.

Saloheimo, Veijo. 1991. Inkerinmaan asutus ja väestö 1618-1700. In: Inkeri: historia, kansa, kulttuuri [Ingermanland: history, people, culture], edited by Pekka Nevalainen and Hannes Sihvo, pp. 68-82. Helsinki: Suomalaisen kirjallisuuden seura.

Saloheimo, Veijo. 1993. Itäsuomalaista liikkuvuutta 1600-luvulla. Savostaja ViipurinKarjalasta poismuuttaneita [Migration in East Finland in the 17th century. Migrants from Savo and Karelia of Vyborg]. Helsinki: Suomen sukututkimusseura.

Shrader, Tatiana. 1989. Pravovaja i kulturnaja adaptatsija nemetskih kolonistov v Peterburgskoj gubernii v poreformennoje vremja [Juridical and cultural adaptation of German colonists in the governorate of St. Petersburg during the reform time]. In: Peterburg i gubernija: istoriko-etnografitsheskije issledovanija [St. Petersburg and its governorate: historic and ethnographic studies], edited by Natalia Juhneva, pp. 132-139. Leningrad.

---. 1998. Poselenija nemetskih krestjan-kolonistov v 19 v. i pervyje dva desjatiletija 20 $v$. [The settlements of German colonists in the 19th century and two decades of the 20th century]. In: Nemtsy v Rossii - Ljudi i sudby [Germans in Russia - People and their destinies], edited by Ljudmila Slavogorodskaja, pp. 81-90. St. Petersburg.

Sihvo, Pirkko. 1991. Savakoita, äyrämöisiä, inkerikoita [Savakkos, Äyrämöinens, Ingrians]. In: Inkeri: historia, kansa, kulttuuri [Ingermanland: history, people, culture], edited by Pekka Nevalainen and Hannes Sihvo, pp. 179-196. Helsinki: Suomalaisen kirjallisuuden seura.

Sivonen, Mika. 2007. "Me inkerikot, vatjalaiset ja karjalaiset". Uskonnollinen integrointi ja ortodoksisen vähemmistön identiteetin rakentuminen Ruotsin Inkerissä 1680-1702 ["We, Ingrians, Votes, Karelians". Religious integration and formation of the identity of Orthodox minority in Swedish Ingermanland 1680-1702]. Helsinki: Suomalaisen Kirjallisuuden Seura.

Svod postanovlenij Sankt-Peterburgskogo ujezdnogo zemskogo sobranija s 1 sentjabrja 1865 g. po 1 janvarja 1872 g. 1872. St. Petersburg.

Tilly, Charles. 1984. Big Structures, Large Processes, Huge Comparisons. New York.

Tjulpanov, Sergej. 1965. Ohtinskij himitsheskij kombinat, 1715 - 1965: Otsherki, dokumenty, vospominanija [Chemical plant of Ohta, 1715-1965: Essays, documents, memoirs]. Leningrad: Izdatelstvo LGU.

Trifonova, Ljudmila. 1999. Othodnitshestvo zaonezhan v Peterburg v kontse $19-$ natshale $20 \mathrm{vv}$. [Seasonal working of population of north of Onega lake in the end of the 19th - in the beginning of 20 century]. Kizhskij vestnik 5: 42-53.

Zarković, Milica. 2002. Ethnic groups in motion: economic competition and migration in multiethnic states. New York: Bookman. 